\title{
Leadership for team learning: the case of university teacher teams
}

\author{
Mieke G.M. Koeslag-Kreunen ${ }^{1,2}$ • \\ Marcel R. Van der Klink ${ }^{1}$ - Piet Van den Bossche $e^{2,3}$ • \\ Wim H. Gijselaers ${ }^{2}$
}

Published online: 20 March 2017

(C) The Author(s) 2017. This article is published with open access at Springerlink.com

\begin{abstract}
Teacher team involvement is considered a key factor in achieving sustainable innovation in higher education. This requires engaging in team learning behaviors that should result in new knowledge and solutions. However, university teachers are not used to discussing their work practices with one another and tend to neglect any innovation in their tasks. Team leadership behavior is often considered essential for stimulating team learning behavior, but it is unclear how this transpires. Therefore, the present study explores university teacher team members' perceptions of team learning behavior, their assigned task, and leadership behaviors in their team. Interviews were conducted with 16 members of different teacher teams at a university of applied sciences. Findings included that the vast majority of the team learning behaviors only involved sharing ideas; engaging in constructive conflicts and co-constructions was not observed. Only a few teams combined all three team learning behaviors. In these teams, members observed that existing methods and solutions were no longer adequate, with leaders appearing to combine transformational and transactional behaviors, but operating from a distance without actively interfering in the process. Furthermore, these team members shared leadership behaviors while focusing on the team as a whole, instead of solving problems at individual level. This strongly indicates that task perception and specific vertical and shared team leadership behaviors play a role in stimulating teachers in seeking controversy and co-constructing new knowledge.
\end{abstract}

Keywords Team learning · Team leadership · Shared leadership · Higher education · Teacher teams · Task perception

Mieke G.M. Koeslag-Kreunen

mieke.koeslag@zuyd.nl; g.koeslag@maastrichtuniversity.nl

1 Research Centre for Educational Innovation and CPD, Zuyd University of Applied Sciences, P.O. Box 550, 6400 AN Heerlen, The Netherlands

2 Department of Educational Research and Development, School of Business and Economics, Maastricht University, P.O. Box 616, 6200 MD Maastricht, The Netherlands

3 Faculty of Social Sciences, University of Antwerp, Sint-Jacobstraat 2, 2000 Antwerp, Belgium 


\section{Introduction}

The consequences of continuous technological improvements, increasing accountability, and changes in working life require new responses from higher education. New modes in the delivery of education, pedagogy, and teaching are often called for (e.g., Barber et al. 2013; Fullan and Scott 2009; Kezar 2011). However, acknowledging the importance of change does not automatically result in successful innovations. University teacher's involvement appears to be a key factor for sustainable educational change (e.g., Emo 2015; Van Driel et al. 1997), and connecting these professionals has been identified as one of the basic requirements for complex change processes to achieve innovation (e.g., Kotter 2012).

In this regard, it has been suggested that encouraging university teachers to work on an innovative task together does play a crucial role in achieving educational change. Innovative tasks are defined here as highly novel, complex, and low-structured (De Dreu and Weingart 2003; Devine 2002; Hoegl et al. 2003). Fullan (2010) suggests that working together on an innovative task potentially offers university teachers the opportunity of combining multiple inputs in identifying the need for innovation, developing ownership, and designing, implementing, and evaluating solutions. Roxå and Mårtensson (2015) argue that collaboration between university teachers takes place in various forms and that collaborative forms of innovation are mainly characterized by a shared responsibility for educational development. However, Vangrieken et al. (2015) question the extent to which collaborating university teachers in fact share and follow up on this responsibility. Cox (2004) observed that university teacher's work tradition is largely solitary, with high levels of individual autonomy. This work tradition also exists in secondary education, with Brouwer et al. (2012) finding that when teachers collaborate, their interdependency is seldom task-related, leading to a low shared outcome responsibility and accountability. Yet, research outside the educational domain also provides ample evidence that teams of professionals that are interdependent and share responsibility can be very successful in tackling innovative tasks (e.g., Lee et al. 2010; Zaccaro et al. 2008).

Such teams are not groups of individual professionals who are loosely coupled for reasons such as simply working in the same department or sharing an interest (Katzenbach and Smith 1993). In contrast, a team is "a collection of individuals who are interdependent in their tasks, who share responsibility for outcomes, who see themselves and who are seen by others as an intact social entity embedded in one or more larger social systems" (Cohen \& Bailey, 1997, p. 241). This task interdependency and shared responsibility distinguishes teams from other forms of collaboration (Katzenbach and Smith 1993). This study uses a team perspective to investigate teacher collaboration for innovation in higher education, first, because teams appear to be very effective for achieving innovation (Zaccaro et al. 2008). Second, Roxå and Mårtensson (2015) reasoned that collaborative forms for innovation in higher education are mainly characterized by sharing a responsibility for educational development. A team approach is in line with that reasoning, because in such an approach, teachers formally share responsibility and task interdependency exists. Third, studies on teacher collaboration are hardly ever conducted in higher education (Kezar 2014; Vangrieken et al. 2015), while overall, there are few studies on effective conditions and outcomes of teacher collaboration for educational innovation (Little 2006; Vescio et al. 2008). Therefore, this study builds on studies performed in organizational and educational contexts (e.g., Crow and Pounder 2000). When describing the context, higher education literature takes precedence, although studies conducted in secondary education were also used where the former was lacking, since the setting has similar features (e.g., Kezar 2014), such as the tradition of professionals working solitarily and autonomously (Brouwer et al. 2012; Cox 2004; Van Waes et al. 2015) and the tendency of teachers to avoid change (Furco and Moely 2012; Van Eekelen et al. 2006). 
Research shows that effective teams with an innovative task can adapt to new situations and develop new knowledge together through engaging in team learning behaviors, which in turn explains their success (Lee et al. 2010; Srivastava et al. 2006). Decuyper et al. (2010) define such behaviors in terms of three essential learning behaviors: sharing, constructive conflict, and coconstruction. Team members who demonstrate all three learning behaviors can build new knowledge, solve complex problems, and develop innovative solutions collectively (Paavola et al. 2004; Van den Bossche et al. 2006). Team effectiveness depends on these team learning behaviors and also encompasses interpersonal factors (Edmondson 1999). In this regard, team psychological safety and team efficacy appear to be conditional for team learning behaviors (Edmondson 1999; Gully et al. 2002).

Despite evidence that a team approach can be successful for innovation in different contexts, simply bringing together university teachers in teams with an innovative task may not be enough (e.g., Fullan and Scott 2009). University teachers' team learning behavior needs to be encouraged for a number of reasons. Firstly, Cox (2004) showed that university teachers operate in a long tradition of solitariness and are not used to sharing and discussing their practices together. It appears that they need to feel safe in a social sense before they engage in such collaborative learning behaviors (Roxå and Mårtensson 2009; Van Waes et al., 2015). Secondly, establishing teams for innovative purposes does not automatically mean that the team members will acknowledge the innovative features of their team task. This is reflected in the review of Timperley et al. (2007), which showed that collaborating secondary school teachers tend to seek support for the status quo and marginalized or even ignored new ideas. This adherence to routine might be also present in higher educational contexts, which could hinder university teacher's need to engage in team learning behaviors. Furco and Moely (2012) showed that university teachers need support from their faculty in taking the perceived risk of sharing practices and co-constructing new methods. Therefore, several authors claim that the readiness of university teacher teams to become engaged in collaborative learning depends heavily on how this is encouraged and facilitated by team leadership (Furco and Moely 2012; Kezar 2005; Roxå and Mårtensson 2009).

Many studies across a wide variety of settings have shown that team leadership behavior plays an important role in fueling team learning behavior (Bucic et al. 2010; Burke et al. 2006; Harris 2011). For example, Lee et al. (2010) found that leaders who inspired and encouraged team members in developing new ideas and trying different approaches supported team learning behaviors in innovative IT teams. Additionally, Bryman (2007) and Van Ameijde et al. (2009) showed that sharing such leadership behaviors can motivate university teachers facing innovative tasks collaboratively, because it provides a sense of team ownership (e.g., Carson et al. 2007; Pearce et al. 2008). However, most studies do not integrate multiple types of leadership behaviors or are mainly focused on the leadership behaviors of a single vertical leader (Avolio et al. 2009). Such research also predominately focuses on team performance as an outcome and not on team learning (Burke et al. 2006; Nicolaides et al. 2014). Moreover, research on the influence of team leadership on teacher team learning is lacking, because empirical studies on stimulating collaborative teacher learning are limited (Little 2006; Vescio et al. 2008) and mostly do not concern teams but collaboration forms with lower levels of task interdependence and shared responsibility (Brouwer et al. 2012; Vangrieken et al. 2015). In addition, these studies have mainly been conducted in primary and secondary education, and rarely in higher education (Kezar 2011; Vangrieken et al. 2015). For these reasons, this study aims to understand how university teacher teams established by the organization learn to deal with their task together. This will be done by exploring the role of team members' perceptions of learning, their task, and the leadership behaviors in their team. 


\section{Learning in teacher teams}

Decuyper et al. (2010) identify three essential team learning behaviors: sharing, constructive conflict, and co-construction. Sharing is defined as "the process of communicating knowledge, competencies, opinions, or creative thoughts of one member to other team members, who were not previously aware that these were present in the team" (Decuyper et al. 2010, p. 116). Constructive conflict is viewed as "a conflict or an elaborated discussion that stems from diversity and open communication, and leads to further communication and some kind of temporary agreement" (Decuyper et al. 2010, p. 117). In a constructive conflict, differences are "negotiated by arguments and clarifications" (Van den Bossche 2006, p. 91). Finally, co-construction refers to the process of developing shared knowledge and building shared meaning "by refining, building on, or modifying an original offer in some way" (Baker, 1994, in Van den Bossche et al. 2006, p. 495). According to Van den Bossche (2006), "the outcome of this process is that 'new' meanings emerge in the collaborative work that were not previously available to the team" (p. 91). All three team learning behaviors are deemed relevant for developing innovative solutions collectively: sharing the available cognitive resources and unique expertise, integrating different viewpoints, and collaboratively building new knowledge (Lee et al. 2010; Paavola et al. 2004).

It is crucial not only to consider the cognitive aspect of team learning but also to include the social process as well (Van den Bossche et al. 2006). Roxå and Mårtensson (2009) showed that university teachers needed to feel safe and to experience mutual trust to engage in collaborative learning behavior, because performing such behaviors is risky and causes uncertainty. This phenomenon has been studied extensively in primary and secondary education, where teachers' traditional work climate is characterized by ignoring differences and pursuing support and consensus, rather than questioning and seeking professional disagreements (Hargreaves 2001). Kwakman (2003) showed that secondary school teachers preferred sharing views only and that they perceived disagreements as threatening instead of viewing them as opportunities to examine opposite views. Van Eekelen et al. (2006) also found that secondary school teachers preferred a predictable, routine approach to work, and therefore tend to avoid risks. According to them, this anxiety caused by change was due to low self-efficacy (Bandura 1997). Therefore, in this paper, we argue that university teacher team learning should be studied as both a cognitive and a social process (e.g., Roxå and Mårtensson 2009; Van den Bossche et al. 2006).

Across domains, psychological safety and team efficacy have been consistently identified as important interpersonal factors for team learning (Decuyper et al. 2010; Gully et al. 2002). Edmondson (1999) referred to team psychological safety as a "sense of confidence that the team will not embarrass, reject or punish someone for speaking up" (p. 354) and added that team members do not feel rejected when putting themselves at risk, for example, by seeking feedback, admitting errors or asking for help. Team efficacy is defined as the collective perceived ability to work together to achieve goals (Bandura 1997). Collins and Parker (2010) showed that a strong belief in a team's abilities leads to more ambitious goals, to the development of strategies to achieve those goals, and to increased persistence in the face of setbacks. Psychological safety and team efficacy might also lead to social support for university teacher team members in taking risks and overcoming problems.

\section{The role of task perception on team learning behavior}

We argue that a team's task is not an objective fact: it depends on its members' perceptions of the task, given their attitudes and work experience. Imants et al. (2013) showed that secondary school 
teachers' perceptions of their collaborative task regarding educational change strongly influenced their attitudes towards engaging in collaborative learning behaviors. Similarly, research in other domains shows that recognizing task features, such as interdependency and innovativeness, can be expected to support team learning behaviors (Hoegl et al. 2003; Van Eekelen et al. 2006). Task interdependency means that "one perceives that one is linked with others in a way so that one cannot succeed unless they do (and vice versa) and/or that one must coordinate one's efforts with the efforts of others to complete a task" (Johnson and Johnson 2003, p. 173). When members see that their effort is needed, they increase their contribution, which subsequently benefits team learning (Johnson and Johnson 2003). Task innovativeness contains three elements: novelty, structure, and complexity. Task novelty is the perceived amount of new or unknown task elements (Edmondson et al. 2007; Hoegl et al. 2003). Task structure refers to the extent to which the task, methods, and outcomes are observed as prescribed/given or open/unpredictable (Ellström 2001). Task complexity involves recognizing the task's difficulty and any absence of standard solutions (Cooke et al. 2001; De Dreu and Weingart 2003).

In contrast to perceiving a task as repetitive or routine, innovative tasks are perceived as highly novel, low-structured, and highly complex (De Dreu and Weingart 2003; Devine 2002; Hoegl et al. 2003), which is argued to trigger team learning behaviors (Edmondson et al. 2003). Perceiving task novelty as high could stimulate team members to collectively develop new solutions instead of adhering to the status quo (Hoegl et al. 2003). Observing lowstructured tasks implies that team members may feel the need to clarify their task, develop new methods, and deal with ambiguous outcomes together (Devine 2002). If team members perceive task complexity as high, this suggests they are more likely to collaborate in order to solve their difficult and unstandardized problem (Cooke et al. 2001; De Dreu and Weingart 2003; Van der Haar et al. 2013).

Ellström (2001) explains the influence of task perception on team learning using two learning levels: adaptive and developmental learning. If team members perceive their task as routine, they are more likely to engage in "adaptive learning." In that case, sharing is considered to be enough for success (Paavola et al. 2004). In contrast, perceiving the task as innovative means it is likely that "developmental learning" will occur (Ellström 2001) for which constructive conflicts and co-constructions are necessary, in addition to sharing (Paavola et al. 2004). Team members' task perception is thus argued to play a role in performing team learning behaviors (Hoegl et al. 2003; Imants et al. 2013). London (2014) also argues that future research should focus on the role of team leadership behavior in influencing team members' task perception and, subsequently, their engagement in either adaptive or developmental learning.

\section{The role of team leadership behavior in supporting university teacher team learning}

Team leadership is repeatedly identified as a critical factor in supporting team learning behaviors (Burke et al. 2006; Harris 2011). Team leadership behaviors refer to the processes of influencing and facilitating, that is, "influencing others to understand and agree about what needs to be done and how it can be done effectively; (...) facilitating individual and collective efforts to accomplish a shared objective" (Yukl, 2002, in Ensley et al. 2006, p. 220). This definition includes two team leadership perspectives: style (i.e., transformational and transactional) and source (i.e., vertical and shared). Bass and Avolio (1994) operationalized the transformational leadership style as leaders who motivate members via behaviors such as articulating a vision, setting high expectations, questioning the status quo, and supporting the 
individual needs. The transactional leadership style consists of behaviors that establish agreements on the tasks, the necessary facilities, and the rewards for achieving them (Bass and Avolio 1994). Transactional leaders also actively monitor team members' performance and take action when mistakes are made. When dealing with an innovative task, it is unlikely that a single, vertical leader will have all the answers and will be able to perform both leadership styles adequately (Day et al. 2004; Timperley et al. 2007). Therefore, a shared team leadership approach is suggested, which Carson et al. (2007) described as team leadership behaviors that stem from multiple sources: the team members themselves.

Thus far, there is no consensus on which style and source of leadership is most effective in supporting team learning (Burke et al. 2006; Nicolaides et al. 2014; Zaccaro et al. 2008). On the one hand, vertical transformational leadership behaviors appear to stimulate team learning on innovative tasks. Moolenaar et al. (2010) found that such behaviors supported secondary school teachers' recognition of innovative task features and their sense of urgency and willingness to collectively develop new knowledge. Furthermore, vertical transformational leadership behaviors appear to support team learning via promoting team psychological safety and team efficacy. Lee et al. (2010), for instance, showed that team leaders who advise and provide new information build interpersonal safety and trust, which explained $69 \%$ of the team knowledge sharing variance (e.g., Edmondson 1999; Srivastava et al. 2006). On the other hand, Timperley et al. (2007) stressed that vertical transactional leadership behaviors are also promising for structuring collaborative teacher learning in (secondary) education. Bucic et al. (2010) and Mebane and Galassi (2003) demonstrated that both vertical transformational and transactional leadership styles encouraged university teacher team learning by challenging teachers to share and by structuring the task. The reviews of London (2014) and Nicolaides et al. (2014) suggest that the most effective leadership style depends on the team's situation, such as the task features or perceived task features, but supporting evidence is limited.

To date, studies that include both leadership styles are scarce and mainly focus on a single, vertical leader (Avolio et al. 2009). However, Van Ameijde et al. (2009) found that teams in higher education benefit from shared leadership behaviors; specifically, this is the case if such behaviors involve collectively building ownership and trust, decision-making, and monitoring performance. Sharing these leadership behaviors and giving university teachers the space to perform them provides them with a degree of autonomy and influence, which can motivate them to solve complex problems collectively (Bryman 2007). Despite the promising influence of shared team leadership, more evidence on how shared leadership behaviors fuel teacher team learning is necessary (Nicolaides et al. 2014). Therefore, this study draws upon both vertical and shared leadership, by considering that transformational and transactional leadership behaviors can both stem from a vertical leader and be shared by the team members (e.g., Bryman 2007; Ensley et al. 2006).

\section{Methodology}

Semi-structured interviews were conducted to explore teacher team members' perceptions of team learning, tasks, and leadership.

\section{Sample and setting}

The study was conducted at a Dutch university of applied sciences offering bachelor's degree programs and professional post-graduate programs. This university uses a team approach to 
deal with complex problems. Team members from various domains (i.e., health care, technology, social sciences, arts, and management) were included, allowing variety and transferability to a broader context (Miles and Huberman 1994). They were purposefully selected (Patton 2002) based on the following four selection criteria (indicated by the faculty management and verified by the interviewees).

1. The team matched the team definition of Cohen and Bailey (1997).

2. The team task required team learning behavior.

3. The minimum team age was 2 months.

4. The minimum team size was three members.

One team member from each team was interviewed in order to provide variety in supporting our explorative aim. In total, 16 teacher team members from 16 different teams participated ( 7 women, 9 men). Participants' university tenure ranged between 8 months and 29 years $(M=10.58$ years, $\mathrm{SD}=9.30$ ). Team assignments such as curriculum design, mentoring, and developing study material were represented. The team size ranged between 3 and 20 members $(M=8.06$ members, $\mathrm{SD}=5.05)$. The team age varied from 8 months to 27 years, $(M=6.65$ years, $\mathrm{SD}=6.39)$.

\section{Interview guideline}

The interview guideline was based on the theoretical framework, containing a main question and several subquestions per topic, which were open-ended, facilitating the explorative aim of this study (Hsieh and Shannon 2005). The questions inventoried the current situation. In development, feedback from three field experts was obtained and a pilot interview carried out. The interview guideline was then finalized (see Table 1 for sample questions).

\section{Procedure}

Each interview lasted $1 \mathrm{~h}$. Before the interview started, a brief introduction was given to the procedure and the research topic, and permission was obtained to audiotape the interview. The interviews were transcribed verbatim and all participants checked their interview transcript.

\section{Coding process}

Software program MAXQDA was used to code the transcripts. The unit of analysis consisted of a "multiple chunk" (Miles and Huberman 1994), which in this study was a meaningful segment in the response of the interviewee represented by a sentence, a part of a sentence, or a set of related sentences. For data analysis, Hsieh and Shannon's (2005) directive content analysis method was followed, and the process consisted of several rounds. Transcript coding started deductively, based on the interview topics. Segments that could not be coded were analyzed and were inductively assigned to a new code or subcode. Literature was consulted to verify and deepen the operationalization of emerging codes. This coding process was repeated several times and tracked in a codebook.

The reliability of identifying meaningful segments was tested in two rounds. First, a member check in an independent research group was carried out to validate the identification of meaningful segments. Second, following the suggestions of Miles and Huberman (1994, p. 64), the first author and another trained peer researcher independently identified meaningful 
Table 1 Codes used and example interview questions

\begin{tabular}{|c|c|c|}
\hline Main code & Subcode & Example interview question \\
\hline \multirow{3}{*}{$\begin{array}{l}\text { Team learning } \\
\text { behaviors }\end{array}$} & Sharing & \multirow{3}{*}{$\begin{array}{l}\text { What kind of (learning) activities do you undertake? } \\
\text { Do you have discussions, how? }\end{array}$} \\
\hline & Co-construction & \\
\hline & Constructive conflict & \\
\hline \multirow[t]{2}{*}{$\begin{array}{l}\text { Interpersonal learning } \\
\text { conditions }\end{array}$} & Team psychological safety & $\begin{array}{l}\text { What do you think of working in this team? } \\
\text { Do you feel comfortable? }\end{array}$ \\
\hline & Team efficacy & $\begin{array}{l}\text { Do you think this team is capable of achieving the } \\
\text { task successfully? Why? }\end{array}$ \\
\hline \multirow[t]{4}{*}{ Task perception } & Task interdependence & \multirow{4}{*}{$\begin{array}{l}\text { Does your team have an assignment? } \\
\text { Could you tell me something about your team } \\
\text { task? }\end{array}$} \\
\hline & Task novelty & \\
\hline & Task structure & \\
\hline & Task complexity & \\
\hline \multirow{5}{*}{$\begin{array}{l}\text { Team leadership } \\
\text { behaviors }\end{array}$} & Vertical transformational & \multirow{5}{*}{$\begin{array}{l}\text { Is someone the leader in your team? } \\
\text { How would you describe his/her activities? }\end{array}$} \\
\hline & leadership behaviors & \\
\hline & $\begin{array}{l}\text { Vertical transactional leadership } \\
\text { behaviors }\end{array}$ & \\
\hline & $\begin{array}{l}\text { Shared transformational } \\
\text { leadership behaviors }\end{array}$ & \\
\hline & $\begin{array}{l}\text { Shared transactional leadership } \\
\text { behaviors }\end{array}$ & \\
\hline
\end{tabular}

segments of a randomly selected $10 \%$ of the data. A total of 68 segments were identified by both researchers, of which an acceptable number of 40 segments (61\%) were identical, meaning the same text was selected. Differences were discussed, and the definition of a meaningful segment was specified.

The transcripts were then coded and the codebook was audited several times in different research groups and at two conferences to test the external validity (Denzin and Lincoln 2011; Miles and Huberman 1994). Subsequently, a new independent second coder was trained, based on the procedures suggested by Neuendorf (2002). A total of $25 \%$ of the randomly selected meaningful segments per transcripts were coded independently. After each transcript, the reliability was calculated and differences were discussed until consensus was reached and revisions were made. The process resulted in an adequate intercoder reliability (Kappa $=0.70)$. Finally, the remaining transcripts were coded and a summary of each transcript was made, which was sent to the participants to check the internal validity (Denzin and Lincoln 2011; Miles and Huberman 1994). Table 1 presents the codes used. Their definitions followed the theoretical framework.

After the coding process, each "task perception" subcode was inductively divided into three levels (i.e., low, mid, and high). Table 2 provides the decision rules, illustrated by an example. Three authors independently assigned each task perception segment to one of the three levels. Differences were discussed until consensus was reached, and the decision rules were further refined. An adequate Kappa of 0.72 was reached.

\section{Data analysis}

Analysis started with the team learning behavior codes. The perceptions of team learning behavior appeared to vary between the interviewees, which was used as a starting point to categorize the data. We tracked which of the three team learning behaviors were mentioned per team member. Three categories emerged: (1) team members that only had segments on sharing; (2) team members with segments on sharing and either constructive conflict or co-construction; and (3) team members with 
Table 2 Decision rules for distinguishing the three levels in task perception

\begin{tabular}{|c|c|c|c|}
\hline Task perception & $\begin{array}{l}\text { Low } \\
\text { The segments... }\end{array}$ & $\begin{array}{l}\text { Mid } \\
\text { The segments... }\end{array}$ & $\begin{array}{l}\text { High } \\
\text { The segments... }\end{array}$ \\
\hline Task interdependence & $\begin{array}{l}\text {... state that the team } \\
\text { member does not need } \\
\text { the others to fulfill the } \\
\text { task. } \\
\text { Example segment for mid } \\
\text { together, but I think we }\end{array}$ & $\begin{array}{l}\text {... contain elements that } \\
\text { the team member is } \\
\text { more or less dependent } \\
\text { on the others to fulfill } \\
\text { the task. } \\
\text { terdependency: "So it was } 1 \\
\text { ould also have done that eac }\end{array}$ & $\begin{array}{l}\text {... state that the team } \\
\text { member needs the } \\
\text { others to fulfill the } \\
\text { task. }\end{array}$ \\
\hline Task novelty & \multicolumn{3}{|c|}{$\begin{array}{l}\text { Example segment for mid novelty: "Innovative is not the right expression, neither } \\
\text { is routine approach. Every student has his own question, }(\ldots) \text { and sometimes } \\
\text { questions are new, resulting in adaptive coaching."(T8Q5) }\end{array}$} \\
\hline Task structure & $\begin{array}{l}\text {... reveal that the task and } \\
\text { method are given but } \\
\text { are new. The results } \\
\text { are also new or open. } \\
\text { Example segment for high } \\
\text { the spine; the content as } \\
\text { the curriculum committ } \\
\text { into a nine-week course }\end{array}$ & $\begin{array}{l}\text { tructure: "We have the assig } \\
\text { vell as the organization. We } 1 \\
\text { and our task is just to furthe } \\
\text { (T2Q2) }\end{array}$ & $\begin{array}{l}\text { nent to develop a course on } \\
\text { ve received an outline from } \\
\text { elaborate on that and turn it }\end{array}$ \\
\hline Task complexity & $\begin{array}{l}\text {... state that the task is } \\
\text { not complex. } \\
\text { Example segment for high } \\
\text { students of different lev } \\
\text { lecturers. And that mak } \\
\text { their own interests, and }\end{array}$ & $\begin{array}{l}\text {... contain elements of } \\
\text { what makes the task } \\
\text { more or less complex. } \\
\text { omplexity: "The special thit } \\
\text { s, with researchers, with wo } \\
\text { it very difficult, because ev } \\
\text { eeir own responsibilities." (T }\end{array}$ & $\begin{array}{l}\text {... state that the task } \\
\text { is complex. } \\
\text { is that you work with } \\
\text { ers from the field, with } \\
\text { yone has their own rhythm, } \\
\text { 6Q3) }\end{array}$ \\
\hline
\end{tabular}

segments on sharing, constructive conflict, and co-construction. These categories imply a continuum that combines Paavola et al.'s (2004) and Ellström's (2001) conceptualization of learning levels discussed earlier: from sharing/adapting knowledge for routine to creating/developing knowledge (constructive conflict and co-constructing) for innovation. Next, we analyzed how the team members in each of the three established categories perceived their team's psychological safety, efficacy, task, and leadership behaviors, exploring how these perceptions varied within and between the three categories. We then labeled the three categories in terms of three team types: coordinative, adaptive, and integrative teams. These labels mirrored the main differences between the categories, given the segments' content within each category.

\section{Results}

Table 3 summarizes the main results categorized by the three team types.

\section{Team learning behavior}

The learning behaviors each team member mentioned (sharing, constructive conflict, and/or co-construction) formed the basis for discerning the three team types. The coordinative team 


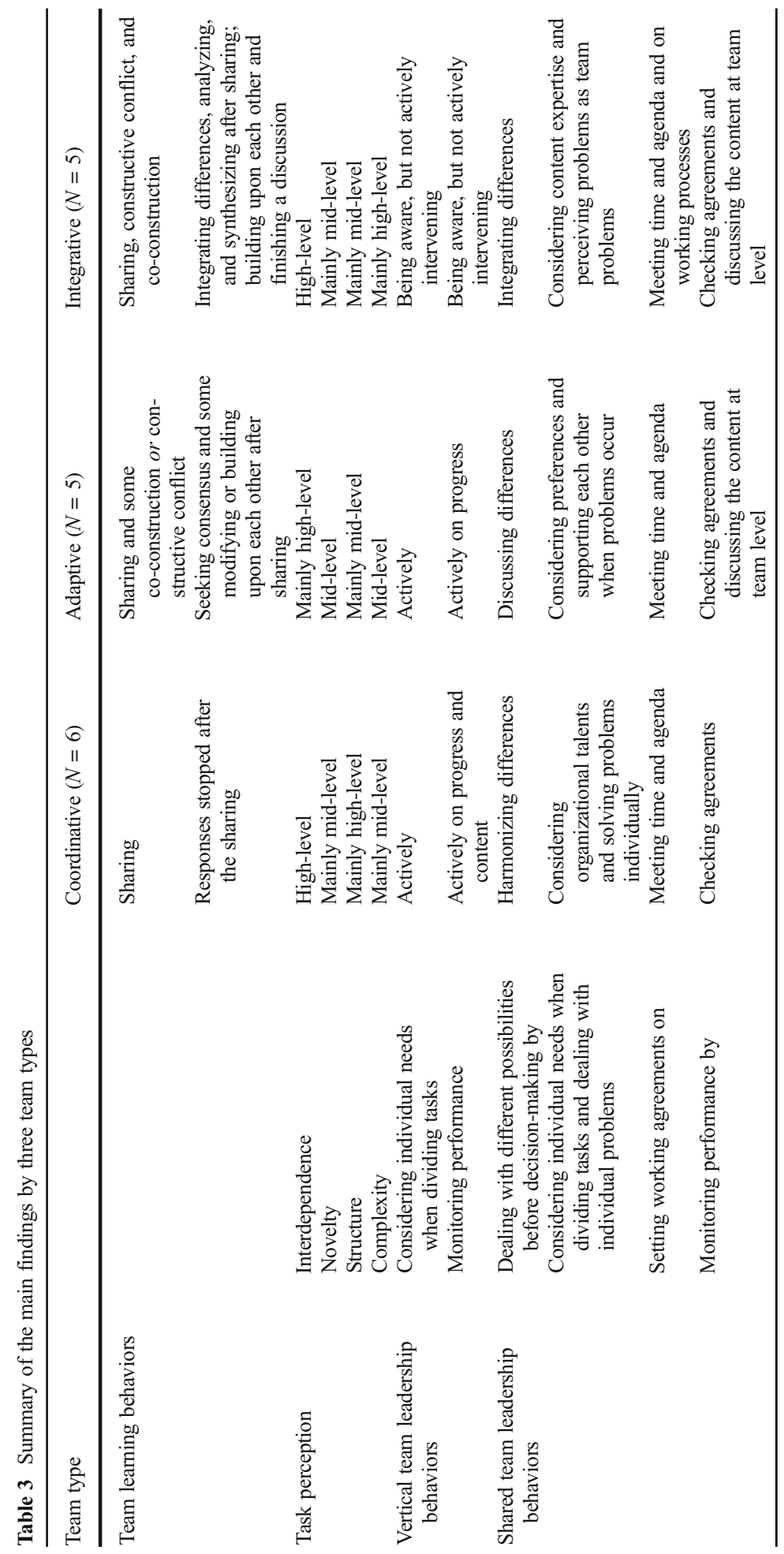


type consisted of six team members who only mentioned sharing activities, such as sharing opinions, thoughts, ideas, and experiences. Building upon each other or modifying each other's input did not occur. Their responses suggested that they coordinated their knowledge, for example:

"Everyone shares loudly. In the beginning it was ill-structured. We've brainstormed." (T3Q20).

The adaptive team type consisted of five team members who reported sharing and either constructive conflict or co-construction. Sharing, and sometimes building upon or modifying each other's input, was mentioned by the team members. Overall, it seemed that these team members mainly sought consensus rather than differences and adapted their knowledge collaboratively, stating, for example:

"Yes, there is discussion, in a sense that we talk about that, but I notice that we always find our way through it." (T5Q15)

The integrative team type consisted of five team members who mentioned a combination of sharing, constructive conflict, and co-construction. Their segments reflected integrating differences, and analyzing or synthesizing the shared thoughts, resulting in some kind of temporary agreement or an agreement to disagree. Their responses indicated that they integrated and developed their knowledge, as reflected in this statement:

"Everyone shares their opinion. And there are different phases. In a brainstorming phase, all opinions are widespread. After a brainstorming phase, you see that you are able to take the important parts, and to shape that and to come to a shared decision.” (T11Q12)

In addition, there were no differences between the team members on their perceptions of team psychological safety and team efficacy. The team members stated that they felt safe enough to speak up $(N=15)$ and stressed that they were capable of achieving the team task together $(N=16)$.

\section{Task perception}

Overall, team members perceived high-level task interdependence $(N=14)$ and mid-level task novelty $(N=11)$. What differed most between the team types were team members' perceptions of task structure and complexity. Within the coordinative team type, almost all team members perceived a high-level structured task $(N=4)$, in contrast to only one within the integrative team type. Just one team member within the coordinative team type perceived task complexity as high-level, in contrast to more than half of the members within the integrative team type $(N=3)$.

\section{Team leadership behaviors}

Vertical, shared, transformational, and transactional leadership behaviors occurred in all team types. However, in-depth content analysis of the coded segments exposed two main differences. Firstly, segments on vertical leadership indicated that leaders of coordinative teams were more actively involved, whereas leaders of integrative teams were aware of team processes but did not actively intervene. Secondly, segments on shared leadership implied that leaders within the coordinative teams were more coordinative and individually focused, whereas in integrative teams, the focus was on integration and content. Six key subcodes for team leadership behavior (see Table 3) clarify these main differences. 
Vertical transformational leadership behaviors concerned (1) "considering individual needs when dividing tasks." Segments within the coordinative team type showed that these team leaders were actively involved in the process and were highly individually focused $(N=3)$. They ensured an equal division of tasks, took all input seriously, and showed that they were committed to each team member:

"The team leader ensures that all tasks are equally divided, and that this happens proportionately. It is someone who also somewhat monitors, like: 'You shouldn't do everything, leave some for the others'." (T1Q30)

Team leaders of the adaptive teams arranged an equal task division by taking each member's planning schedule and energy into account $(N=3)$. In contrast, team members of the integrative team types mentioned that their leaders were aware of the team process and individual needs but did not actively interfere in the process $(N=2)$.

(2) "Monitoring performance" was a key subcode for vertical transactional leadership behaviors. Team members within the coordinative team type mentioned that their team leaders monitored the agenda, asked for progress, and took a stand in discussions $(N=4)$. Furthermore, segments within adaptive teams indicated that these leaders confronted members on following up team decisions $(N=2)$. Again, team leaders of integrative teams showed the opposite: they monitored but did not actively intervene in the process or the content $(N=1)$ :

"Being aware of what everyone does, without meddling in everything." (T2Q31)

Shared transformational leadership behaviors differed as follows. (3) "Dealing with different possibilities before decision-making" showed members within the coordinative team type harmonized differences $(N=3)$; the adaptive team type discussed differences $(N=3)$, and the integrative team type integrated differences to make a decision together $(N=1)$. (4) "Considering individual needs when dividing tasks and dealing with individual problems" showed that team members within the coordinative team type managed task division by using their own organizational talents and solved individual problems individually $(N=3)$. The segments within the adaptive team type indicated tasks were divided based on member's preferences, and they supported each other when problems occurred $(N=3)$ :

"I know that I'm not alone in this. When I say 'I am too busy at the moment, I can't make it', then I know I'll get support.” (T5Q32)

In contrast, the team members within the integrative team type divided tasks based on their own expertise and perceived individual problems as team problems $(N=3)$. Additionally, they initiated process evaluations and collectively monitored the psychological safety.

Shared transactional leadership behaviors concerned two key subcodes. Analyses on (5) "setting working agreements" showed that the team members within the coordinative $(N=4)$ and adaptive team types $(N=1)$ mentioned that they focused on arranging agreements on the meeting time and the agenda, whereas team members within the integrative team types also explained they focused on setting working processes agreements $(N=2)$ :

"We consider the action points, and we say: "Who does what?' Followed by: 'In two

weeks this is done, and then we discuss that again in the group'." (T2Q33) 
Finally, (6) "monitoring performance" also differed: interviewees within the coordinative team type said that they checked if all team members did what they agreed upon $(N=4)$, whereas the team members within the adaptive $(N=3)$ and integrative team types $(N=3)$ also discussed the content at team level after the individual tasks were carried out:

"We divide the tasks, but after that we also discuss what we have done and if we've succeeded. And we also ask: 'Please check if this is in line with the intention'." (T2Q34)

\section{Conclusions and discussion}

This study aims to understand how university teacher teams learn together to deal with their task and therefore explores the role of team members' perceptions of learning, their task, and leadership behaviors in their team. This resulted in four main findings.

\section{University teacher team learning appears to be present, but not in abundance}

First, the learning behaviors each team member mentioned formed the basis for discerning three team types: coordinative, adaptive, and integrative. The coordinative and adaptive team types stopped after sharing, sought consensus, and either harmonized (coordinative team type) or adapted (adaptive team type) existing knowledge and practices. In contrast, the integrative team type engaged in constructive conflicts, integrated their differences, and co-constructed new ideas or solutions. This finding aligns with Kwakman's (2003) study among secondary school teachers: the majority of our sample (69\%) also preferred just sharing views. Roxå and Mårtensson (2009) found that it is important for university teachers to feel safe in order to openly discuss their existing practices. However, our data suggest that psychological safety and team efficacy were perceived as high by all team types. This indicates that experiencing high levels of psychological safety and team efficacy might not be enough to seek controversy for building new knowledge and finding solutions together.

\section{Observing that standard methods and solutions are inadequate}

Second, our findings indicate that members, who perceived that standard methods and solutions were inadequate to deal with the task, also mentioned constructive conflicts and co-constructions in addition to sharing. Other authors suggest that recognizing such an innovative task feature could form a basis for team members to move beyond sharing and challenge the status quo collaboratively (De Dreu and Weingart 2003; Ellström 2001; Paavola et al. 2004). However, our findings also suggest that university teachers do not necessarily recognize such features. Similarly, Roxå and Mårtensson (2009) showed that university teachers tend to shy away from controversial ideas that may cause conflict. This might be all right for a routine task, but Paavola et al. (2004) argued that creating innovative solutions requires more than just sharing.

\section{Vertical team leadership behaviors from a distance}

Third, teacher team learning behavior seemed to benefit from vertical transformational and vertical transactional leadership behaviors. This finding aligns with Bucic et al. (2010) and Mebane and 
Galassi (2003) who found that both vertical leadership styles were related to university teacher team learning. Our data further specify this by suggesting that leaders in integrative team types were aware of the process but did not actively interfere. Similarly, Bryman (2007) concluded that effective leaders in higher education empower teams and monitor from a distance.

\section{Sharing integrative and content-focused leadership behaviors}

Finally, our findings further elaborate earlier claims that shared leadership, in general, is suited to teacher teams, by suggesting that instead of smoothing out differences and checking tasks together, discussing and integrating differences and content at the team level might be supportive for team learning. Moreover, regarding discussions and solving individual problems, members within the integrative team type were focused on the team as a whole, whereas the coordinative and adaptive team types tended to keep such activities on an individual level. Similarly, Yukl (2009) argued that leadership behaviors that focus on connecting team members stimulate team learning behaviors.

\section{Limitations and recommendations for further research}

The present study is explorative and small scale. Nevertheless, it offers rich, in-depth information suggesting that university teacher team's learning behaviors vary and that task perception and different team leadership behaviors play a role in that regard. Future research is necessary to establish how to further investigate the influence of team leadership's focus on team learning, beyond the traditional level of style and source. Specifically, our findings recommend developing further understanding of how team learning behavior in teams dealing with open tasks with unconventional methods and outcomes are stimulated by leadership behaviors from a distance and by sharing a focus on content and integration. These leadership behaviors were also identified in integrative team types; perhaps integrative teams develop, accept, or foster such behaviors. A longitudinal study could provide more understanding on how leadership can influence coordinative teams into becoming adaptive or integrative. ${ }^{1}$ Our findings imply that leadership plays a role in encouraging university teachers to leave their comfort zone to seek controversy and challenge the status quo together in teams, as well as to subsequently coconstruct new knowledge and practices for sustaining higher education's added value.

\section{Compliance with ethical standards}

Funding Financial support of this study was partially provided by a grant from the Network Social Innovation of Maastricht University, the Netherlands. This was used for the purchase of data analysis software, conference presentations, and transcribing the interviews.

Conflict of interest The authors declare that they have no conflict of interest.

Open Access This article is distributed under the terms of the Creative Commons Attribution 4.0 International License (http://creativecommons.org/licenses/by/4.0/), which permits unrestricted use, distribution, and reproduction in any medium, provided you give appropriate credit to the original author(s) and the source, provide a link to the Creative Commons license, and indicate if changes were made.

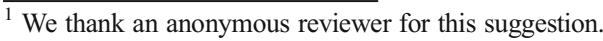




\section{References}

Avolio, B. J., Walumbwa, F. O., \& Weber, T. J. (2009). Leadership: current theories, research, and future directions. Annual Review of Psychology, 60, 421-449. doi:10.1146/annurev.psych.60.110707.163621.

Baker, M. (1994). A model for negotiation in teaching-learning dialogues. Journal of Artificial Intelligence in Education, 5(2), 199-254.

Bandura, A. (1997). Self-efficacy: the exercise of control. New York: Freeman.

Barber, M., Donnelly, K., \& Rizvi, S. (2013). An avalanche is coming: higher education and the revolution ahead. London: Institute for Public Policy Research.

Bass, B., \& Avolio, B. J. (1994). Improving organizational effectiveness through transformational leadership. Thousand Oaks: SAGE Publications.

Brouwer, P., Brekelmans, M., Nieuwenhuis, L., \& Simons, R.-J. (2012). Fostering teacher community development: a review of design principles and a case study of an innovative interdisciplinary team. Learning Environments Research, 15(3), 319-344. doi:10.1007/s10984-012-9119-1.

Bryman, A. (2007). Effective leadership in higher education: a literature review. Studies in Higher Education, 32(6), 693-710. doi:10.1080/03075070701685114.

Bucic, T., Robinson, L., \& Ramburuth, P. (2010). Effects of leadership style on team learning. Journal of Workplace Learning, 22(4), 228-248. doi:10.1108/13665621011040680.

Burke, C. S., Stagl, K. C., Klein, C., Goodwin, G. F., Salas, E., \& Halpin, S. M. (2006). What type of leadership behaviors are functional in teams? A meta-analysis. The Leadership Quarterly, 17(3), 288-307. doi:10.1016 /j.leaqua.2006.02.007.

Carson, J. B., Tesluk, P. E., \& Marrone, J. A. (2007). Shared leadership in teams: an investigation of antecedent conditions and performance. Academy of Management Journal, 50(5), 1217-1234. doi:10.2307/20159921.

Cohen, S. G., \& Bailey, D. E. (1997). What makes teams work: Group effectiveness research from the shop floor to the executive suite. Journal of Management, 23(3), 239-290. doi:10.1177/014920639702300303.

Collins, C. G., \& Parker, S. K. (2010). Team capability beliefs over time: distinguishing between team potency, team outcome efficacy, and team process efficacy. Journal of Occupational and Organizational Psychology, 83(4), 1003-1023. doi:10.1348/096317909X484271.

Cooke, N. J., Kiekel, P. A., \& Helm, E. E. (2001). Measuring team knowledge during skill acquisition of a complex task. International Journal of Cognitive Ergonomics, 5(3), 297-315. doi:10.1207/S15327566IJCE0503_10.

Cox, M. D. (2004). Introduction to faculty learning communities. New Directions for Teaching and Learning, 2004(97), 5-23. doi:10.1002/tl.129.

Crow, G. M., \& Pounder, D. G. (2000). Interdisciplinary teacher teams: context, design, and process. Educational Administration Quarterly, 36(2), 216-254. doi:10.1177/0013161X00362004.

Day, D. V., Gronn, P., \& Salas, E. (2004). Leadership capacity in teams. The Leadership Quarterly, 15(6), 857880. doi:10.1016/j.leaqua.2004.09.001.

De Dreu, C. K. W., \& Weingart, L. R. (2003). Task versus relationship conflict, team performance, and team member satisfaction: a meta-analysis. Journal of Applied Psychology, 88(4), 741-749. doi:10.1037/00219010.88.4.741.

Decuyper, S., Dochy, F., \& Van den Bossche, P. (2010). Grasping the dynamic complexity of team learning: An integrative model for effective team learning in organisations. Educational Research Review, 5(2), 111-133. doi:10.1016/j.edurev.2010.02.002.

Denzin, N. K., \& Lincoln, Y. S. (Eds.). (2011). The SAGE handbook of qualitative research (4th ed.). Thousand Oaks: SAGE Publications.

Devine, D. J. (2002). A review and integration of classification systems relevant to teams in organizations. Group Dynamics: Theory, Research, and Practice, 6(4), 291-310. doi:10.1037//1089-2699.6.4.291.

Edmondson, A. C. (1999). Psychological safety and learning behavior in work teams. Administrative Science Quarterly, 44(2), 350-383. doi:10.2307/2666999.

Edmondson, A. C., Roberto, M. A., \& Watkins, M. D. (2003). A dynamic model of top management team effectiveness: managing unstructured task streams. The Leadership Quarterly, 14(3), 297-325. doi:10.1016 /S1048-9843(03)00021-3.

Edmondson, A. C., Dillon, J. R., \& Roloff, K. S. (2007). Three perspectives on team learning. The Academy of Management Annals, 1(1), 269-314. doi:10.1080/078559811.

Ellström, P.-E. (2001). Integrating learning and work: problems and prospects. Human Resource Development Quarterly, 12(4), 421. doi:10.1002/hrdq.1006.

Emo, W. (2015). Teachers' motivations for initiating innovations. Journal of Educational Change, 16(2), 171195. doi:10.1007/s10833-015-9243-7.

Ensley, M. D., Hmieleski, K. M., \& Pearce, C. L. (2006). The importance of vertical and shared leadership within new venture top management teams: implications for the performance of startups. The Leadership Quarterly, 17(3), 217-231. doi:10.1016/j.leaqua.2006.02.002. 
Fullan, M. (2010). All systems go: The change imperative for whole system reform. Thousand Oaks. CA: SAGE Publications.

Fullan, M., \& Scott, G. (2009). Turnaround leadership for higher education. San Francisco: Jossey-Bass.

Furco, A., \& Moely, B. E. (2012). Using learning communities to build faculty support for pedagogical innovation: a multi-campus study. Journal of Higher Education, 83(1), 128-153.

Gully, S. M., Incalterra, K. A., Joshi, A., \& Beaubien, J. M. (2002). A meta-analysis of team-efficacy, potency, and performance: interdependence and level of analysis as moderators of observed relationships. Journal of Applied Psychology, 87(5), 819-832.

Hargreaves, A. (2001). The emotional geographies of teachers' relations with colleagues. International Journal of Educational Research, 35(5), 503-527. doi:10.1016/S0883-0355(02)00006-X.

Harris, A. (2011). System improvement through collective capacity building. Journal of Educational Administration, 49(6), 624-636. doi:10.1108/09578231111174785.

Hoegl, M., Praveen Parboteeah, K., \& Gemuenden, H. G. (2003). When teamwork really matters: task innovativeness as a moderator of the teamwork-performance relationship in software development projects. Journal of Engineering and Technology Management, 20(4), 281-302. doi:10.1016/j. jengtecman.2003.08.001.

Hsieh, H.-F., \& Shannon, S. E. (2005). Three approaches to qualitative content analysis. Qualitative Health Research, 15(9), 1277-1288. doi:10.1177/1049732305276687.

Imants, J., Wubbels, T., \& Vermunt, J. D. (2013). Teachers' enactments of workplace conditions and their beliefs and attitudes toward reform. Vocations and Learning, 6(3), 323-346. doi:10.1007/s12186-013-9098-0.

Johnson, D. W., \& Johnson, R. T. (2003). Training for cooperative group work. In M. A. West, D. Tjosvold, \& K. G. Smith (Eds.), International handbook of organizational teamwork and cooperative working (pp. 167184). London: Wiley.

Katzenbach, J. R., \& Smith, D. K. (1993). The wisdom of teams: creating the high-performance organization. Boston: Harvard Business School Press.

Kezar, A. (2005). Redesigning for collaboration within higher education institutions: an exploration into the developmental process. Research in Higher Education, 46(7), 831-860. doi:10.1007/s11162-004-6227-5.

Kezar, A. (2011). What is the best way to achieve broader reach of improved practices in higher education? Innovative Higher Education, 36(4), 235-247. doi:10.1007/s10755-011-9174-z.

Kezar, A. (2014). Higher education change and social networks: a review of research. The Journal of Higher Education, 85(1), 91-125. doi:10.1353/jhe.2014.0003.

Kotter, J. P. (2012). Accelerate! Harvard Business Review, 90(11), 45-58 Retrieved from https://hbr.org/2012/11 /accelerate.

Kwakman, K. (2003). Factors affecting teachers' participation in professional learning activities. Teaching and Teacher Education, 19(2), 149-170. doi:10.1016/S0742-051X(02)00101-4.

Lee, P., Gillespie, N., Mann, L., \& Wearing, A. (2010). Leadership and trust: their effect on knowledge sharing and team performance. Management Learning, 41(4), 473-491. doi:10.1177/1350507610362036.

Little, J. W. (2006). Professional community and professional development in the learning-centered school. Arlington: Education Association National.

London, M. (2014). Team processes for adaptive and innovative outcomes. Team Performance Management: an International Journal, 20(1/2), 19-38. doi:10.1108/TPM-05-2013-0012.

Mebane, D., \& Galassi, J. (2003). Variables affecting collaborative research and learning in a professional development school partnership. The Journal of Educational Research, 96(5), 259-268. doi:10.1080 /00220670309597638.

Moolenaar, N. M., Daly, A. J., \& Sleegers, P. J. C. (2010). Occupying the principal position: examining relationships between transformational leadership, social network position, and schools' innovative climate. Educational Administration Quarterly, 46(5), 623-670. doi:10.1177/0013161X10378689.

Miles, M. B., \& Huberman, A. M. (1994). Qualitative data analysis: an expanded sourcebook (2nd ed.). Thousand Oaks: SAGE Publications.

Neuendorf, K. A. (2002). The content analysis guidebook. Thousand Oaks: SAGE Publications.

Nicolaides, V. C., LaPort, K. A., Chen, T. R., Tomassetti, A. J., Weis, E. J., Zaccaro, S. J., \& Cortina, J. M. (2014). The shared leadership of teams: a meta-analysis of proximal, distal, and moderating relationships. The Leadership Quarterly. doi:10.1016/j.leaqua.2014.06.006.

Paavola, S., Lipponen, L., \& Hakkarainen, K. (2004). Models of innovative knowledge communities and three metaphors of learning. Review of Educational Research, 74(4), 557-576. doi:10.3102/00346543074004557.

Patton, M. Q. (2002). Qualitative research and evaluation methods (3rd ed.). Thousand Oaks: SAGE Publications.

Pearce, C. L., Conger, J. A., \& Locke, E. A. (2008). Shared leadership theory. The Leadership Quarterly, 19(5), 622-628. doi:10.1016/j.leaqua.2008.07.005.

Roxå, T., \& Mårtensson, K. (2009). Significant conversations and significant networks - exploring the backstage of the teaching arena. Studies in Higher Education, 34(5), 547-559. doi:10.1080/03075070802597200. 
Roxå, T., \& Mårtensson, K. (2015). Microcultures and informal learning: a heuristic guiding analysis of conditions for informal learning in local higher education workplaces. International Journal for Academic Development, 20(2), 193-205. doi:10.1080/1360144X.2015.1029929.

Srivastava, A., Bartol, K. M., \& Locke, E. a. (2006). Empowering leadership in management teams: effects on knowledge sharing, efficacy and performance. Academy of Management Journal, 49(6), 1239-1251. doi:10.5465/AMJ.2006.23478718.

Timperley, H., Wilson, A., Barrar, H., \& Fung, I. (2007). Teacher professional learning and development. Best evidence synthesis iteration (BES). Wellington: Ministry of Education . Retrieved from http://www. educationcounts.govt.nz/_data/assets/pdf_file/0017/16901/TPLandDBESentire.pdf.

Van Ameijde, J. D. J., Nelson, P. C., Billsberry, J., \& Van Meurs, N. (2009). Improving leadership in higher education institutions: a distributed perspective. Higher Education, 58(6), 763-779. doi:10.1007/s10734009-9224-y.

Van den Bossche, P. (2006). Minds in teams: the influence of social and cognitive factors on team learning. Maastricht: Datawyse. http://arno.unimaas.nl/show.cgi?fid=6493. Accessed 31 May 2013.

Van den Bossche, P., Gijselaers, W., Segers, M., \& Kirschner, P. (2006). Social and cognitive factors driving teamwork in collaborative learning environments: team learning beliefs and behaviors. Small Group Research, 37(5), 490-521. doi:10.1177/1046496406292938.

Van der Haar, S., Segers, M., \& Jehn, K. A. (2013). Towards a contextualized model of team learning processes and outcomes. Educational Research Review, 10, 1-12. doi:10.1016/j.edurev.2013.04.001.

Van Driel, J. H., Verloop, N., Van Werven, I. H., \& Dekkers, H. (1997). Teachers' craft knowledge and curriculum innovation in higher engineering education. Higher Education, 34(1), 105-122. doi:10.1023 /A:1003063317210.

Van Eekelen, I. M., Vermunt, J. D., \& Boshuizen, H. P. A. (2006). Exploring teachers' will to learn. Teaching and Teacher Education, 22(4), 408-423. doi:10.1016/j.tate.2005.12.001.

Van Waes, S., Van den Bossche, P., Moolenaar, N.M., Stes, A., \& Van Petegem, P. (2015). Uncovering changes in university teachers' professional networks during an instructional development program. Studies in Educational Evaluation, 46, 11-28. doi:10.1016/j.stueduc.2015.02.003.

Vangrieken, K., Dochy, F., Raes, E., \& Kyndt, E. (2015). Teacher collaboration: a systematic review. Educational Research Review, 15, 17-40. doi:10.1016/j.edurev.2015.04.002.

Vescio, V., Ross, D., \& Adams, A. (2008). A review of research on the impact of professional learning communities on teaching practice and student learning. Teaching and Teacher Education, 24(1), 80-91. doi:10.1016/j.tate.2007.01.004.

Yukl, G. (2002). Leadership in organizations. Upper Sad- dle River. NJ: Prentice-Hall.

Yukl, G. (2009). Leading organizational learning: reflections on theory and research. The Leadership Quarterly, 20(1), 49-53. doi:10.1016/j.leaqua.2008.11.006.

Zaccaro, S. J., Ely, K., \& Shuffler, M. (2008). The leader's role in group learning. In V. Sessa \& M. London (Eds.), Work group learning, understanding, improving and assessing how groups learn in organizations (pp. 15-44). Mahwah: Lawrence Erlbaum Associates. 